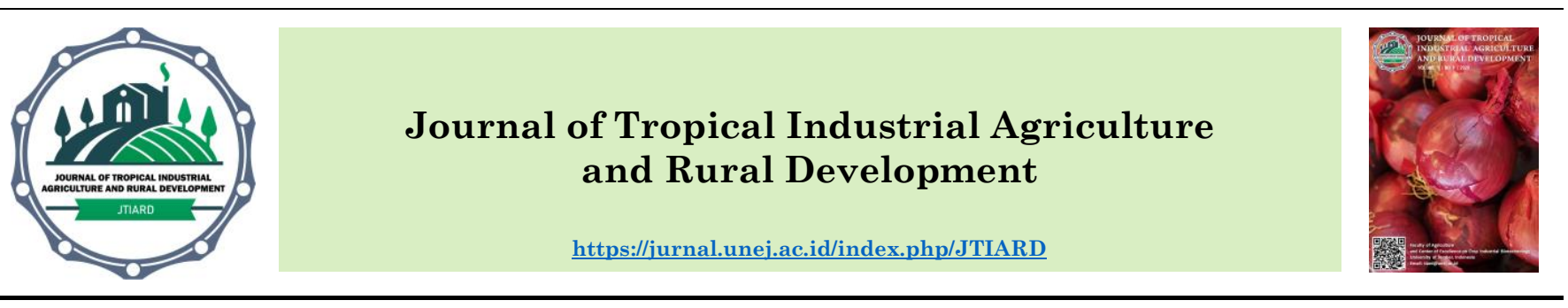

\title{
The exploration of Bacillus spp. as antagonist agents against Xanthomonas axonopodis pv. glycines from the weed phyllosphere in soybean plantation
}

\author{
Suhartiningsih Dwi Nurcahyanti and Dipta Linggar Wisma Ning Ayu \\ Faculty of Agriculture, University of Jember. Jalan Kalimantan No. 37, Tegal Boto Campus, Jember 68121
}

\begin{abstract}
Bacterial pustules caused by Xanthomonas axonopodis pv. glycines (Xag) is one of the important diseases in soybean plants. Bacillus bacteria from the soybean phyllosphere have the potential to inhibit these pathogens. Weed phyllosphere in soybean plantations is also a good habitat for Bacillus life. The purpose of this study was to obtain Bacillus from the weed phyllosphere which has the potential as an antagonistic agent against Xag. The study methods included exploration, screening, and physio-biochemical identification. The results obtained 31 isolates and 22 of them were able to inhibit Xag with various inhibitory properties. Five strains of Bacillus spp. had large inhibitory effects against Xag, namely strain Bp 2(2), Jg3(3), Bg d1(1), Jg 1(3) and Jg 1(4)1. The Bacillus strain Bp2(2) had the largest inhibition zone witht $15 \mathrm{~mm}$ and strain $\mathrm{Jg} 1(4) 1$ had the fastest colony growth with $68 \mathrm{~mm}$. Five Bacillus spp had different growth capability based on the environmental condition and carbon source. The physiobiochemical identification results indicated that Bacillus strain Jg 3(6), Bg d 1(1), Jg 1(3), Jg 1(4)1 had the similar characteristics to $B$. licheniformis, while strain Bp 2(2) had the similar characteristics to $B$. coagulans.
\end{abstract}

Keywords: Bacillus; phyllosphere; weeds; Xanthomonas axonopodis pv. glycines.

\section{INTRODUCTION}

The soybean requirement in Indonesia annually increases as soybean is the main source of plant proteins utilized to fulfill the people nutrition (Rudini and Ayustaningwarno, 2013), carbohydrates and lipids (Astawan et al., 2014). According to the Indonesian Central Bureau of Statistics (2016), the soybean plant production in Indonesia were fluctuative since 1993 until 2015. This condition was due to the various factors as one of which was because of the plant-disturbing

\author{
ARTICLE INFO \\ Corresponding Author: \\ Suhartiningsih Dwi Nurcahyanti \\ suhartingsih.faperta@unej.ac.id \\ Received: 04 December 2019 \\ Accepted: 04 May 2020 \\ Published: 10 June 2020
}

DOI: 10.19184/jtiard.v1i1.16411

How to cite:

Nurcahyanti SN, DLWN Ayu (2020). The exploration of Bacillus spp. as antagonist agents against Xanthomonas axonopodis pv. glycines from the weed phyllosphere in soybean plantation. J. Trop. Ind. Agric. Rural Dev. 1(1): 17-26 
Brandl, 2003), rhizosphere (Bustaman et al., 2006), rhizoplane (Cazorla et al., 2007). Phyllosphere is the leaf surface region affected by physical and chemical factors that affect the microbial development on the leaf surface. Pseudomonas fluorescens, $P$. putida, P. syringae, Erwinia agglomerans, Curtobacterium, Bacillus pumilus, B. mycoides are bacterial microbe types on the leaf phyllosphere (Kucheryava et al., 1999).

According to Stein (2005), Bacillus is an antagonistic agent used as a biocontrol due to producing peptide antibiotics, namely subtilisin, subtilosin, bacilysin, and surfactin. B. pumilus is capable of producing bacitracin compounds (Awais et al., 2007). Bacillus isolated from the corn plant phyllosphere was capable of suppressing Exerohilum turcicum in-vitro (Sartoni et al., 2015). The study results of Wartono et al. (2015) explained that $B$. subtilis as biocontrol agents could suppress the development of bacterial leaf blight disease caused by $X$. oryzae pv. oryzae bacteria (Xoo) until 21.7\%.

According to Sumartini and Rahayu (2017), weeds that live among plants are the alternative hosts used by the microorganisms to sustain their life cycles. Weeds that abundantly dominate the soybean plantation are Cynodon dactylon, Cyperus rotundus, Digitaria ciliaris, Eclipta alba (Prayogo et al., 2017). Accordingly, it is necessary to perform an exploration of Bacillus from weed phyllosphere as an antagonistic agent against Xag. This is given as Bacillus and Xag are from the same habitat, namely phyllosphere, therefore it is expected that Bacillus obtained can suppress Xag, when applied as an antagonistic agent.

\section{MATERIAL AND METHOD}

\section{Isolate of Xanthomonas axonopodis pv. glycines}

$X$. axonopodis pv. glycines isolate used was the collection of Plant Disease Laboratory, Plant Protection, Faculty of Agriculture, University of Jember. Bacteria were cultured on the Yeast Peptone Glucose Agar (YPGA) medium with the incubation period of 48 hours at the room temperature, then confirmed through Gram, hypersensitive response (HR), and pathogenicity test (Schaad et al., 2001).

\section{Bacillus Exploration and Isolation}

Weed samples were taken from the soybean plantation in Jember Regency region, East Java, from several locations with different geographical conditions. Weed samples were taken from some points on the soybean plantation.

Isolation was performed using the method of Nurfitriani et al. (2016) and Arwiyanto (1997). The weed leaves were cut $1 \times 1 \mathrm{~cm}$ and $1 \mathrm{~g}$ of cut leaves were moved into the $20 \mathrm{ml}$ sterile water and shaken for 30 minutes. The bacterial suspension was taken $1 \mathrm{ml}$ and moved into the test tube containing $9 \mathrm{ml}$ sterile water. The suspension was heated at $80^{\circ} \mathrm{C}$ for 10 minutes, then made a serial dilution. One hundred microliters suspension on $10^{5}$ dilutions was grown on YPGA media and incubated for 48 hours at the room temperature. The bacterial colonies grown were purified and performed Gram and hypersensitive test.

Gram test was done through on ose needle of 48hour bacteria were put on the object glass and dropped $3 \% \mathrm{KOH}$, then stirred and lifted slowly (Chun \& Vidaver in Schaad et al., 2001). Hypersensitive test was assayed using a bacterial suspension with the density of $10^{8} \mathrm{cfu} / \mathrm{ml}$ was injected on the tobacco leaf and incubated at the room temperature for 72 hours (Chun \& Vidaver in Schaad et al., 2001). The morphological characterization was performed by observing a bacterial colony, including the colony shape, color, margin, and elevation based on Capuccino and Sherman (1992).

\section{Bacillus Screening}

Bacterial screening was conducted by performing the antagonistic test using a dual platting method (Nurcahyanti et al., 2013). Bacteria were grown on the YPGA media with a sterile toothpick and incubated for 48 hours at the room temperature. Petri dish was flipped and 1 $\mathrm{mL}$ chloroform was dropped on the lid, then stood for 2 hours at the room temperature. The petri dish position was returned, then Xag suspension was poured onto the media surface as much as $200 \mu \mathrm{L}$

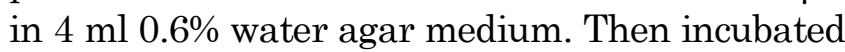
for 24 hours at the room temperature and measured the inhibition zone formed by measuring the inhibition zone radius on the four colony margin sides. The inhibition mechanism test was performed by taking the agar media on the inhibition zone and moved into the test tube containing $0.5 \%$ peptone water. The bacteria growth observation was performed for five days by viewing the media opacity. 


\section{Bacillus characterization}

The characterization of Bacillus spp. was performed by testifying their physio-biochemical character based on the characteristics and methods described by Chun \& Vidaver (in Schaad et al., 2001).

Growth test at $45^{\circ} \mathrm{C}$ and $65^{\circ} \mathrm{C}$. The 48 -hour bacteria were suspensed in the sterile water and as much as $75 \mu \mathrm{l}$ was grown on $1 \%$ liquid peptone media, then incubated at $45^{\circ} \mathrm{C}$ and $65^{\circ} \mathrm{C}$. Opacity was observed for 5 days of incubation period. The positive reaction showed as the media turned opaque.

Growth test at $p H$ 5.7. The 48-hour bacteria were suspended in the sterile water and as much as $75 \mu \mathrm{l}$ was grown on $1 \%$ liquid peptone media with $\mathrm{pH}$ 5.7. Opacity was observed for 5 days of incubation period. The positive reaction showed as the media turned opaque.

Growth test at 7\% $\mathrm{NaCl}$. The 48-hour bacteria were suspensed in the sterile water and as much as $75 \mu \mathrm{l}$ was grown on $1 \%$ liquid peptone media with $7 \% \mathrm{NaCl}$. The bacterial growth observation was performed for 14 days.

Anaerobic growth test in glucose broth. One ose of 48-hour bacteria was grown on Hugh and Leifson's OF glucose broth media, which were put in anaerobic condition. The anaerobic condition was formed by pouring a sterile paraffin with the depth of $1 \mathrm{~cm}$ and incubated at $24^{\circ} \mathrm{C}$. The observation was performed for 14 days against the media color alteration from blue-green to yellow.

Acid production test. The test was performed using mannitol-dextrose as the carbon source. One ose needle of 48-hour bacteria was grown on Hugh and Leifson's OF glucose broth media, which were put in anaerobic condition. The anaerobic condition was formed by pouring a sterile paraffin with the depth of $1 \mathrm{~cm}$ and incubated at $24^{\circ} \mathrm{C}$. The observation was performed for 14 days against the media color alteration from blue-green to yellow.
Starch hydrolysis test. The 48-hour bacteria were grown on the starch medium, then incubated for 2 days at the room temperature and dropped a starch reagent.

Catalase test. The 48-hour bacteria were moved into the object glass using an ose needle, then dropped $\mathrm{H}_{2} \mathrm{O}_{2}$ and mixed slowly.

\section{RESULT DAN DISCUSSION}

\section{Rejuvenation of $X$. axonopodis pv. glycines}

Xag isolates showed a colony with yellow, circular, mucoid, flat margin, Gram negative, and capable of hydrolyzing starch (Sain and Gur, 2013). A positive HR test indicated that the bacteria are pathogenic and virulent, which are capable of causing leaf pustules (Figure 1).

\section{Bacillus exploration}

The isolation results from 11 weed species of several locations obtained 31 isolates survived at $80^{\circ} \mathrm{C}$ with Gram positive, HR negative, nonpathogenic characteristics on the soybean. These isolates were suspected as Bacillus (Table 1). Bacillus can live at an extreme temperature as forming a sustained structure to survive. Bacteria of the Bacillus genus can form endospore which make these species survive against physical and chemical factors (Hatmanti, 2000), namely an extreme temperature, $\mathrm{pH}$, and salinity (Pratita and Putra, 2012).

The following exploration results had various morphologies and mostly showed a milky color, irregular shape, irregular margin, rough surface, and unmucoid (Table 2). The phyllospheric microbial community are varied with highly abundant and variation which is also affected by the leaf area and thickness, organic materials, region climate, as well as exudates removed by the plants (Thomson et al., 1993).
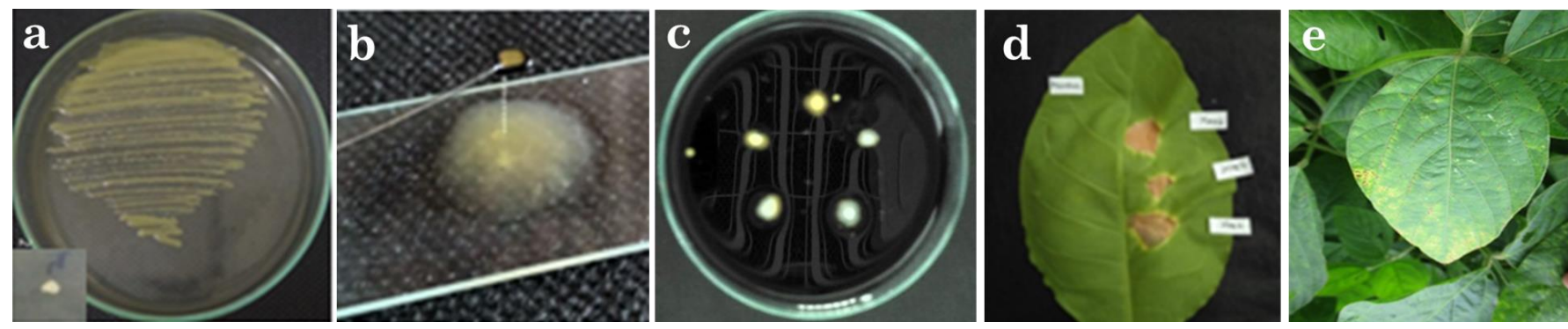

Figure 1. X. axonopodis pv. glycines bacteria, (a) Xag colony, (b) Gram test (Gram negative), (c) Starch hydrolysis test (positive), (d) Hypersensitive reaction and pathogenicity test (positive) 
Table 1. Bacillus spp. isolates from weed phyllosphere

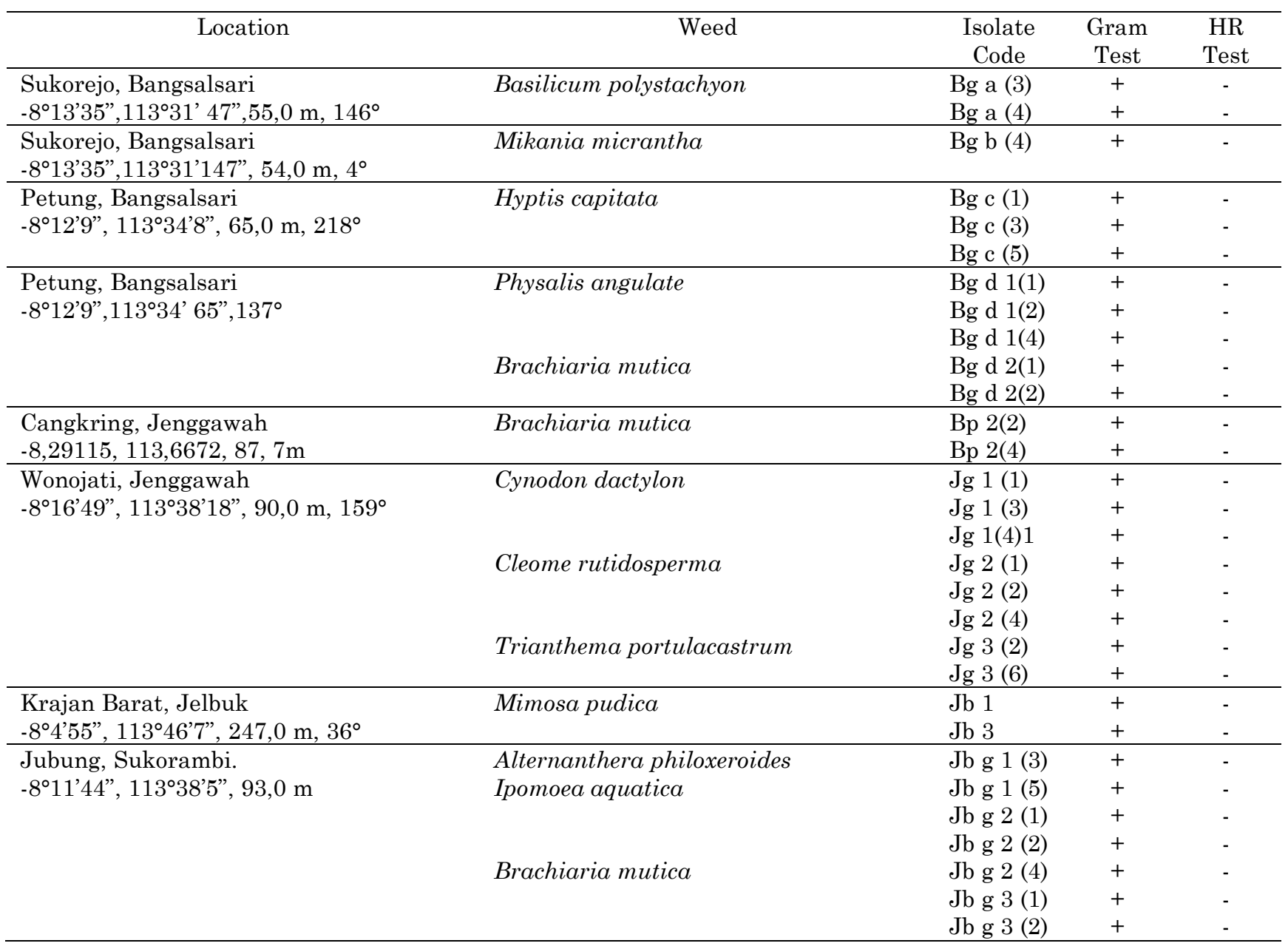

Table 2. Bacillus spp. morphological characteristics

\begin{tabular}{|c|c|c|c|c|c|}
\hline \multirow{2}{*}{ No } & \multirow{2}{*}{ Isolate code } & \multicolumn{4}{|c|}{ Colony Morphology } \\
\hline & & Color & Shape & Margin & Elevation \\
\hline 1 & $\mathrm{Bg}$ a (3) & Pale white & Irregular & Irregular & Rough \\
\hline 2 & $\mathrm{Bg}$ a (4) & Pale white & Irregular & Irregular & Rough \\
\hline 3 & Bg b (4) & Pale white & Irregular & Entire & Flat \\
\hline 4 & $\mathrm{Bg}$ c (1) & Pale white & Irregular & Irregular & Flat \\
\hline 5 & Bg c (3) & Colorless & Circular & Undulate & Convex \\
\hline 6 & Bg c (5) & Pale white & Circular & Entire & Convex \\
\hline 7 & $\operatorname{Bg~d~1(1)~}$ & Pale white & Irregular & Irregular & Flat \\
\hline 8 & $\operatorname{Bg~d~1(2)~}$ & Pale white & Irregular & Irregular & Flat \\
\hline 9 & $\operatorname{Bg~d~1(4)~}$ & Pale white & Irregular & Irregular & Flat \\
\hline 10 & $\operatorname{Bg~d~2(1)~}$ & Pale white & Irregular & Irregular & Flat \\
\hline 11 & $\operatorname{Bg} d 2(2)$ & Pale white & Circular & Entire & Convex \\
\hline 12 & $\operatorname{Bg~d~2(3)~}$ & Pale white & Circular, mucoid & Entire & Flat \\
\hline 13 & Bp $2(2)$ & Pale white & Irregular & Irregular & Flat \\
\hline 14 & Bp 2 (4) & Pale white & Irregular & Irregular & Rough \\
\hline 15 & Jg 1 (1) & Colorless & Circular, mucoid & Irregular & Convex \\
\hline
\end{tabular}


Table 2. Bacillus spp. morphological characteristics (continued)

\begin{tabular}{|c|c|c|c|c|c|}
\hline \multirow{2}{*}{ No } & \multirow{2}{*}{ Isolate code } & \multicolumn{4}{|c|}{ Colony Morphology } \\
\hline & & Color & Shape & Margin & Elevation \\
\hline 16 & Jg $1(3)$ & Milky & Irregular & Irregular & Rough \\
\hline 17 & $\operatorname{Jg} 1(4) 1$ & Pale white & Irregular & Irregular & Flat \\
\hline 18 & $\operatorname{Jg} 2(1)$ & Pale white & Circular, mucoid & Entire & Flat \\
\hline 19 & Jg 2(2) & Pale white & Irregular & Irregular & Rough \\
\hline 20 & Jg 2(4) & Pale white & Irregular & Irregular & Rough \\
\hline 21 & $\mathrm{Jg} 3(2)$ & Pale white & Irregular, mucoid & Irregular & Flat \\
\hline 22 & Jg $3(6)$ & Pale white & Irregular & Irregular & Rough \\
\hline 23 & $\mathrm{Jb}(1)$ & Pale white & Irregular & Entire & Rough \\
\hline 24 & $\mathrm{Jb}(3)$ & Pale white & Irregular & Irregular & Flat \\
\hline 25 & Jbg 1 (3) & Colorless & Circular, mucoid & Entire & Convex \\
\hline 26 & $\operatorname{Jbg} 1$ (5) & Pale white & Irregular & Irregular & Flat \\
\hline 26 & $\operatorname{Jbg} 2(1)$ & Pale white & Irregular, mucoid & Irregular & Convex \\
\hline 28 & Jbg $2(2)$ & Pale white & Irregular & Irregular & Flat \\
\hline 29 & $\operatorname{Jbg} 2(4)$ & Colorless & Circular, mucoid & Entire & Flat \\
\hline 30 & $\operatorname{Jbg} 3(1)$ & Pale white & Irregular & Irregular & Flat \\
\hline 31 & Jbg 3 (2) & Colorless & Irregular & Undulate & Convex \\
\hline
\end{tabular}

Table 3. Bacillus spp. capabilities in inhibiting Xag

\begin{tabular}{|c|c|c|c|c|c|}
\hline No. & Isolate code & $\begin{array}{c}\text { Inhibitory zone against } \\
\text { Xag }(\mathrm{mm})\end{array}$ & No. & Isolate code & $\begin{array}{c}\text { Inhibitory zone against } \\
\text { Xag }(\mathrm{mm})\end{array}$ \\
\hline 1 & $\mathrm{Bg}$ a (3) & 3 & 17 & Jg 1 (4) 1 & 8.5 \\
\hline 2 & $\mathrm{Bg}$ a (4) & 0 & 18 & Jg $2(1)$ & 0 \\
\hline 3 & $\mathrm{Bg} b(4)$ & 4 & 19 & $\operatorname{Jg} 2(2)$ & 0 \\
\hline 4 & Bg c (1) & 6 & 20 & $\operatorname{Jg} 2(4)$ & 0 \\
\hline 5 & $\mathrm{Bg}$ c (3) & 0 & 21 & Jg $3(2)$ & 7 \\
\hline 6 & $\mathrm{Bg}$ c (5) & 0 & 22 & Jg $3(6)$ & 11 \\
\hline 7 & $\operatorname{Bg} d 1(1)$ & 10 & 23 & $\mathrm{Jb}(1)$ & 5 \\
\hline 8 & Bg d 1 (2) & 3 & 24 & $\mathrm{Jb}(3)$ & 3.5 \\
\hline 9 & $\operatorname{Bg} d 1(4)$ & 2 & 25 & Jbg 1 (3) & 6 \\
\hline 10 & Bg d 2 (1) & 4 & 26 & $\operatorname{Jbg} 1(5)$ & 7 \\
\hline 11 & $\operatorname{Bg} d 2(2)$ & 2 & 27 & Jbg 2 (1) & 2.5 \\
\hline 12 & Bg d 2 (3) & 0 & 28 & Jbg 2 (2) & 0 \\
\hline 13 & Bp 2 (2) & 15 & 29 & Jbg 2 (4) & 7.7 \\
\hline 14 & Bp 2 (4) & 8 & 30 & Jbg 3 (1) & 4 \\
\hline 15 & Jg 1 (1) & 0 & 31 & Jbg 3 (2) & 7 \\
\hline 16 & Jg 1 (3) & 9.5 & & & \\
\hline
\end{tabular}

\section{Bacillus spp. screening}

The inhibitory effect test results of Bacillus spp. against Xag obtained 22 isolates were capable of inhibiting Xag pathogen and 9 other isolates did not show an inhibition (Table 3). This capability was shown from the occurrence of clear zone formed around Bacillus spp. colony. 22 isolates showed varied clear zones from 2 until $15 \mathrm{~mm}$ (Table 3). The study result of Marcic et al. (2018) presented that Bacillus spp. had various abilities to inhibit $X$. vesicatoria and Clavibacter michiganensis subsp. michiganensis. The inhibitory mechanism of all Bacillus spp. against Xag were bacteriostatic, which means that Bacillus spp. are inhibiting and not lethal. This was suspected as Bacillus spp. produced certain compounds and Xag bacteria were sensitive against the compounds, therefore disrupting the metabolism process in the bacterial cell and causing an inhibited bacterial growth. 
Table 4. The characteristics of five Bacillus spp. strain as potential antagonistic agents against Xag

\begin{tabular}{|c|c|c|c|c|c|}
\hline $\begin{array}{c}\text { Bacterial } \\
\text { colony } \\
\text { (48 hours) } \\
\end{array}$ & Characteristic & Isolate origin & $\begin{array}{c}\text { Colony } \\
\text { diameter } \\
(\mathrm{mm})\end{array}$ & $\begin{array}{l}\text { Inhibitory } \\
\text { zone (mm) }\end{array}$ & $\begin{array}{l}\text { Inhibitory } \\
\text { mechanism }\end{array}$ \\
\hline $\mathrm{Bp} 2(2)$ & $\begin{array}{l}\text { Pale white color, rough } \\
\text { surface, irregular shape, } \\
\text { irregular margin, flat } \\
\text { elevation. }\end{array}$ & Brachiaria mutica & 45 & 15 & Bacteriostatic \\
\hline & $\begin{array}{l}\text { Pale white color, rough } \\
\text { surface, irregular shape, } \\
\text { irregular margin, flat } \\
\text { elevation. }\end{array}$ & $\begin{array}{l}\text { Trianthema } \\
\text { portulacastrum }\end{array}$ & 9 & 11 & Bacteriostatic \\
\hline $\operatorname{Bg} d 1$ (1) & $\begin{array}{l}\text { Pale white color, rough } \\
\text { surface, irregular shape, } \\
\text { irregular margin, flat } \\
\text { elevation. }\end{array}$ & Physalis angulata & 25 & 10 & Bacteriostatic \\
\hline Jg 1 (3) & $\begin{array}{l}\text { milky color, rough surface, } \\
\text { irregular shape, irregular } \\
\text { margin, flat elevation. }\end{array}$ & Cynodon dactylon & 47 & 9.5 & Bacteriostatic \\
\hline Jg 1 (4) 1 & $\begin{array}{l}\text { Pale white color, rough } \\
\text { surface, irregular shape, } \\
\text { irregular margin, flat } \\
\text { elevation. }\end{array}$ & Cynodon dactylon & 68 & 8.5 & Bacteriostatic \\
\hline
\end{tabular}
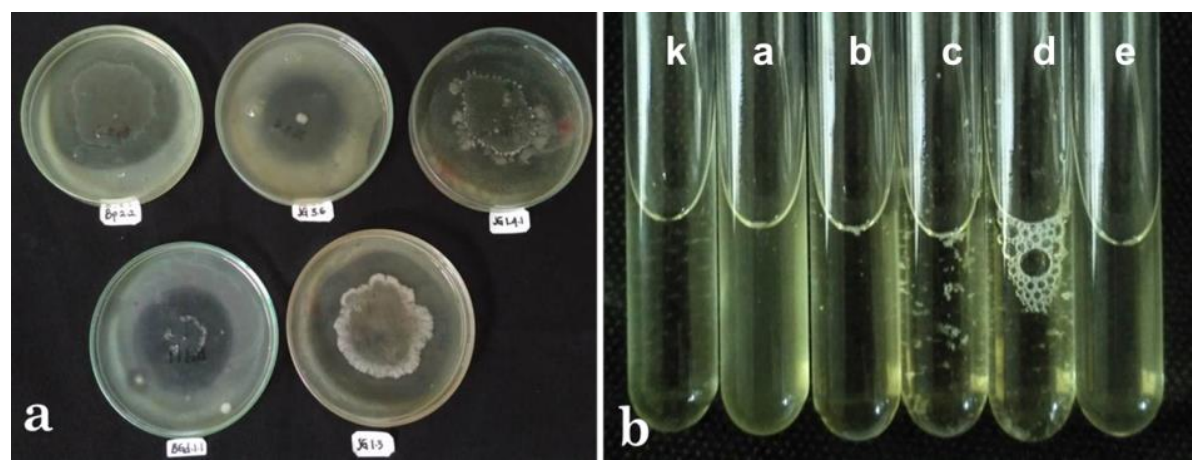

Figure 2. The Bacillus spp. isolate inhibition against Xag. Note: (a) inhibitory zone formation, (b) five Bacillus spp. isolates inhibitory mechanism : k) control a) Bp2(2), b) Jg3(6), c) Jg1(4), d) Bg d1(1), e) Jg1(3) 


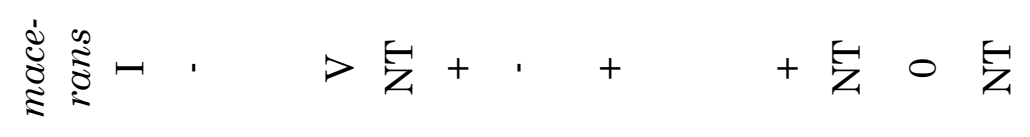

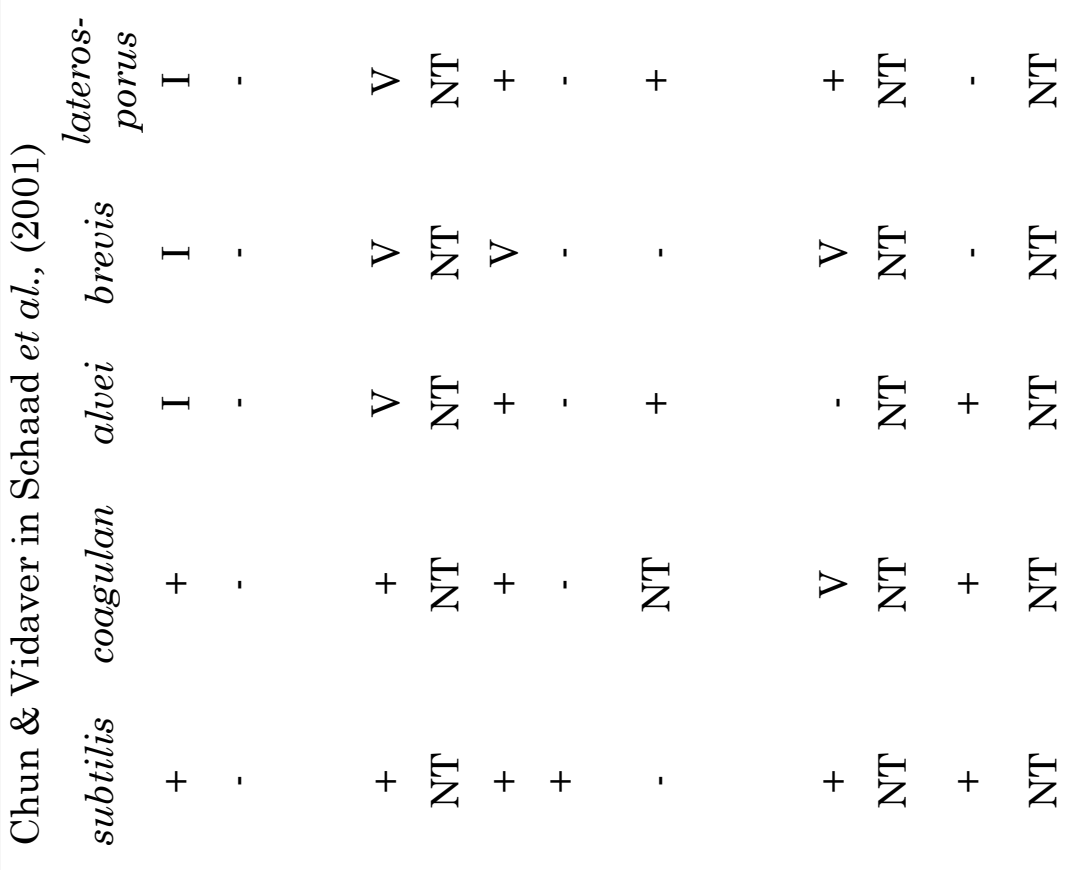

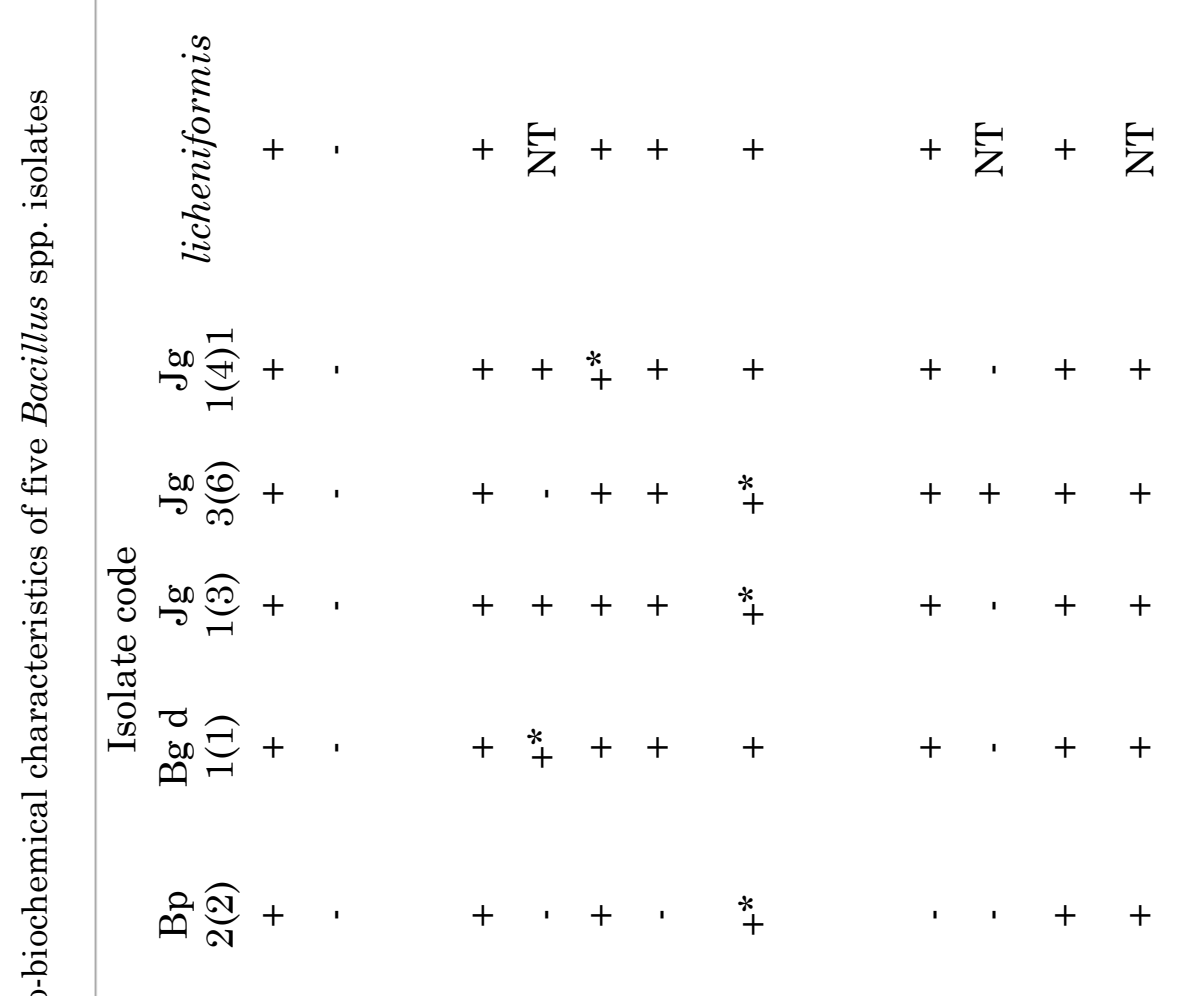

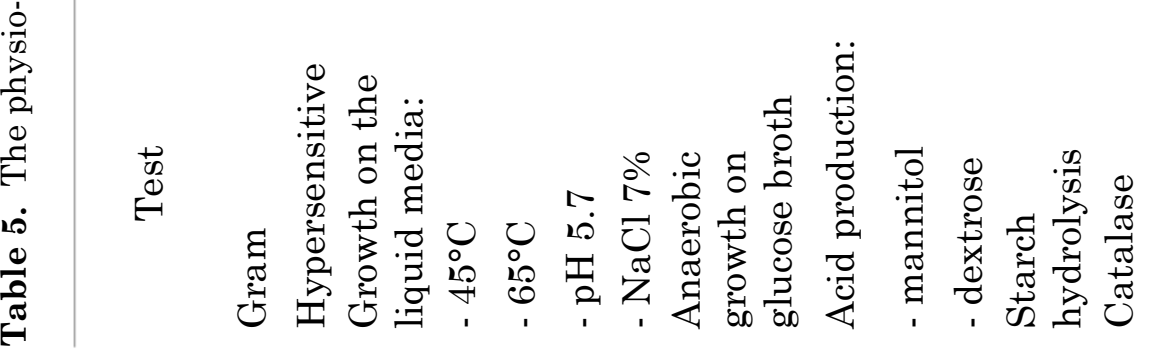


Table 6. The living capability of five Bacillus spp. on the environmental condition and carbon source

\begin{tabular}{|c|c|c|c|c|c|c|c|}
\hline Isolate code & $45^{\circ} \mathrm{C}$ & $65^{\circ} \mathrm{C}$ & $\begin{array}{c}\mathrm{NaCl} \\
7 \%\end{array}$ & $\mathrm{pH} 5,7$ & $\begin{array}{l}\text { Anaerobic growth in } \\
\text { glucose broth }\end{array}$ & Mannitol & Dextrose \\
\hline control & - & - & - & - & - & - & - \\
\hline Jg 1(3) & +++ & + & +++ & ++ & + & + & - \\
\hline Jg 3(6) & +++ & - & ++++ & + & + & + & + \\
\hline Jg 1(4)1 & ++ & + & +++ & ++ & ++ & ++ & - \\
\hline $\operatorname{Bg~d~1(1)~}$ & ++ & + & +++ & ++ & ++ & + & - \\
\hline $\mathrm{Bp} 2(2)$ & ++ & - & - & + & + & + & - \\
\hline
\end{tabular}
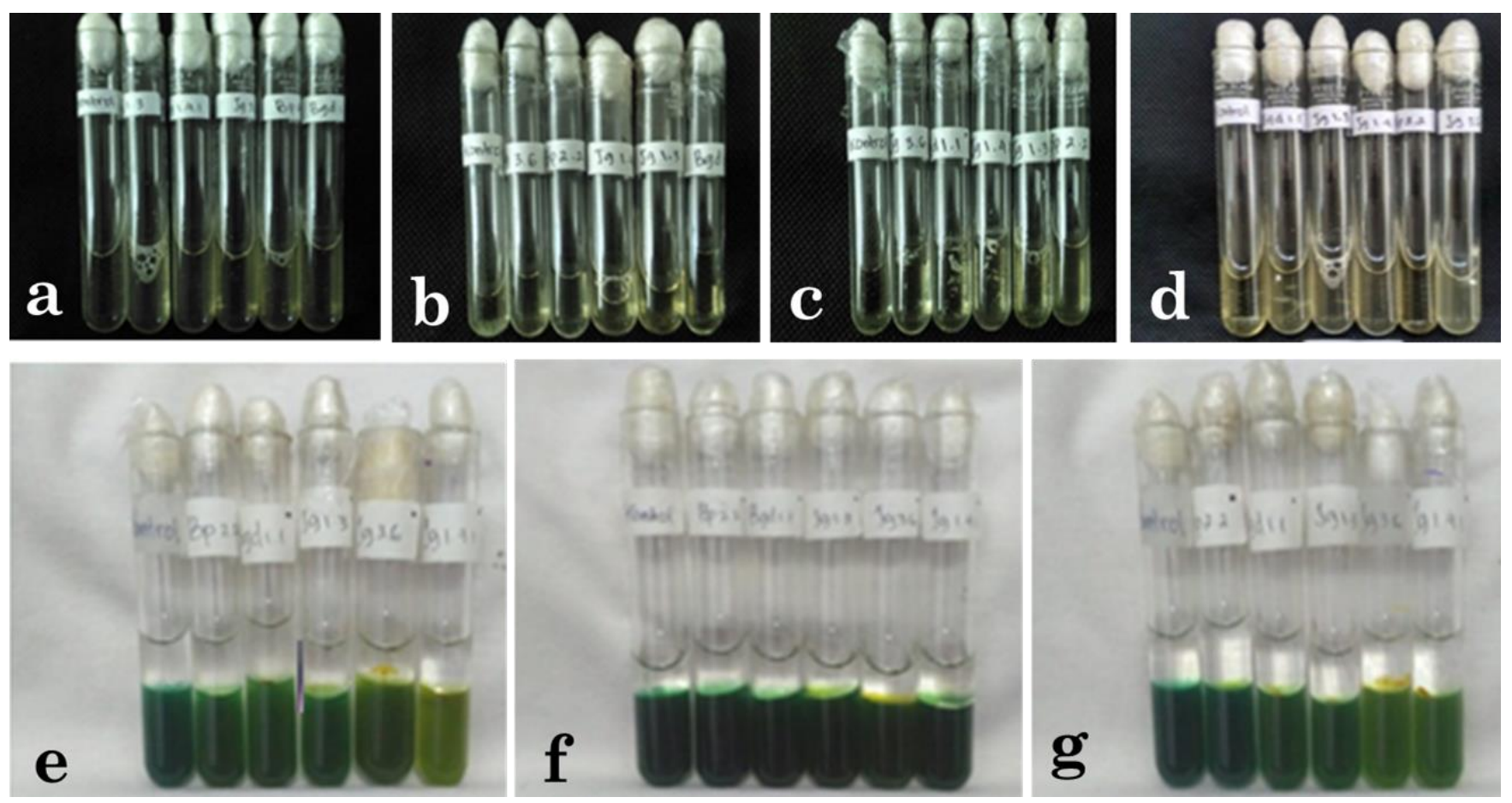

Figure 3. The living capability of five Bacillus spp. (a) growth at $45^{\circ} \mathrm{C}$, (b) growth at $65^{\circ} \mathrm{C}$, (c) pH 5,7 ; (d) $\mathrm{NaCl} 7 \%$, (e) glucose carbon source utilization, (f) dextrose carbon source utilization, (g) mannitol carbon source utilization.
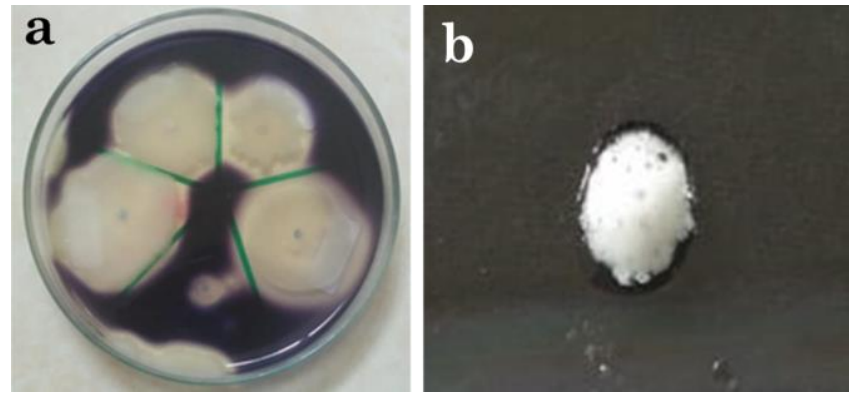

Figure 4. Bacillus spp. test, (a) Starch hydrolysis (positive), (b) Catalase (positive)

According to Soesanto (2013), Bacillus can play the role as plant pathogen biocontrol agent through the antibiotic mechanism by producing the antimicrobial compounds, namely antibiotics, peptides, phenolic compounds, enzymes, alkaloids, and siderophore. B. subtilis is capable of producing antibiotics in the form of bacitracin and subtilin. According to Javandira et al. (2013), those antibiotic compounds will inhibit the protein synthesis on bacteria, therefore inhibiting the growth.

Based on the capabilities of Bacillus spp. in inhibiting Xag, five potential isolates were chosen as antagonistic agents based on the diameter of inhibition zone. These five isolates were Bp 2(2), Jg 3(6), Bg d 1(1), Jg 1(3) and Jg 1(4)1 with various characteristics (Table 4, Figure 2). The Jg1(4)1 isolate showed the largest colony diameter with 68 $\mathrm{mm}$, while the largest inhibition zone against Xag was obtained from $\mathrm{Bp} 2(2)$ isolate. The growth of Jg1(4)1 isolate as the largest colony shows a shorter generation period, therefore the bacterial population increases in faster period. The $\mathrm{Bp} 2(2)$ 
isolate had the largest inhibitory effect was suspected as producing high content of inhibitory compounds or more various compound types, therefore the inhibitory capability was larger than other isolates. As an antagonistic agent, Bacillus which has faster growth capability play the role on inhibition mechanism in the form of competitions, either growth space or nutrient. Bacillus with large inhibitory effect will be able to suppress the metabolism process better, therefore the pathogenic bacterial will be more inhibited. On the inhibitory mechanism test, it showed that Jg1(4) 1 and $\mathrm{Bg} \mathrm{d1(1)} \mathrm{isolate} \mathrm{formed} \mathrm{an} \mathrm{aggregate} \mathrm{against}$ Xag growth, while other isolates grew spreading on the liquid media.

The physio-biochemical test results (Table 5) showed that Bacillus strain Jg 3(6), Bg d 1(1), Jg 1(3), Jg 1(4)1 had the similar characteristics to $B$. licheniformis and $\mathrm{Bp} 2(2)$ was similar to $B$. coagulans.

Five Bacillus sp. isolates had some similarities in the physio-biochemical tests, however having different growth capabilities on the temperature, $\mathrm{NaCl}$ content, media acidity, and carbon source (Table 6, Figure 3). Each isolate has its own advantages to survive on different environmental condition and capability of utilizing the carbon source. This diversity is suspected to cause Bacillus spp. can grow together as a phyllospheric community.

Bacillus was capable of hydrolyzing the starch marked by the occurrence of the clear zone around the bacterial colonies after given some drops of iodine solution (Figure 4). The clear zone around the bacterial colonies indicated that starch in the media had been hydrolyzed by amylase enzyme produced by the bacteria to become simplified sugar compounds. According to Amri et al. (2010), the bacterial capability of producing amylase is determined by the structural gene existence or absence, which regulates the amylase protein synthesis inside the bacterial cell. Catalase test results performed showed positive results. This was marked by the occurrence of gas bubbles on each Bacillus isolate dropped with $\mathrm{H}_{2} \mathrm{O}_{2}$. According to Suhartanti et al. (2010), the occurrence of catalase activity can be known from the $\mathrm{O}_{2}$ gas bubbles formed. Hydrogen peroxide $\left(\mathrm{H}_{2} \mathrm{O}_{2}\right)$ can be decomposed by catalase enzyme produced by the microorganisms to become $\mathrm{H}_{2} \mathrm{O}+\mathrm{O}_{2}$.

The exploration results obtained five Bacillus spp. strains that had the largest inhibitory effect against Xag, namely strain Bp 2(2), Jg3(3), Bg d1(1), Jg 1(3) and Jg 1(4)1. Strain Bp 2(2) had the largest inhibition zone with $15 \mathrm{~mm}$ and $\mathrm{Jg} 1(4) 1$ showed the fastest colony growth with $68 \mathrm{~mm}$. The physio-biochemical test results showed that Bacillus strain Jg 3(6), Bg d 1(1), Jg 1(3),Jg 1(4)1 had similar characteristics to $B$. licheniformis and Bp 2(2) was similar to B. coagulans.

\section{ACKNOWLEDGEMENT}

This study was funded by the research grant for supporting IsDB under the University of Jember rector decision letter Number: 12509/UN25/ LT/2018 and contract letter number: 4077/ UN25.3.1/LT.1/2018 September 28, 2018.

\section{REFERENCES}

Amri E, N Widhyastuti, IM Artika. 2010. Aktivitas amilase bakteri yang diisolasi dari sumber air panas Ciseeng Bogor. Saintek 2(1): 23-33.

Arwiyanto T. 1997. Pengendalian hayati penyakit layu penyakit tembakau: 1. Isolasi bakteri antagonis. Perlindungan Tanaman Indonesia 3(1): 54-60.

Astawan M, NR Adiningsih, NS Palupi. 2014. Evaluasi kualitas nuget dari berbagai varietas kedelai. Pangan 23(3): 244-255.

Awais M, AA Shah, A Hamed, F Hasan. 2007. Isolation, Identification and optimization of bacitracin produced by Bacillus sp. Pak. J. Bot. 39(4): 1303-1312.

Badan Pusat Statistika. 2016. Produksi Kedelai Menurut Kabupaten Kota di Jawa Timur Tahun 2007-2016. Jawa Timur: Badan Pusat Statistik, Indonesia.

Bustamam H. 2006. Seleksi mikroba rizosfer antagonis terhadap bakteri Ralstonia solanacearum penyebab penyakit layu bakteri pada tanaman jahe di lahan tertindas. Jurnal Ilmu-ilmu Pertanian Indonesia 8(1): $12-18$.

Cappucino JG, N Sherman. 1992. Microbiology a Laboratory Manual 3rd Edition. Calif Redwood City, California: The Benjamin Cummings Publishing Company Inc.

Cazorla, FM, D Romero, AP Garzia, BJJ Lugtenberg, A de Vicente, G Bloemberg. 2007. Isolation and characterization of antagonistic Bacillus subtilis strains from the avocado rhizoplane displaying biocontrol activity. Appl. Microbiol. 103(1): 1950-1959.

Hatmanti A. 2000. Pengenalan Bacillus sp. Oseana 25(1): $31-41$.

Javandira C, LQ Aini, AL Abadi. 2013. Pengendalian penyakit busuk lunak umbi kentang (Erwinia carotovora) dengan memanfaatkan agens hayati Bacillus subtilis dan Pseudomonas fluorescens. Jurnal Hama dan Penyakit Tumbuhan 1(1): 90-98.

Kucheryava N, M Fiss, G Auling, RM Kropenstedt. 1999. Isolation and characterization of epiphytic bacteria 
from the phyllosphere of apple, antagonistic in vitro to Venturia inaequalis, the causal agent of apple scab. Syst. Appl. Microbiol. 22(1): 472-478.

Lindow SE, MT Brandl. 2003. Microbiology of the phyllosphere. Appl. Environ. Microbiol. 69(4): 18751883.

Marcic ST, V Todorovic, O Stanojevic, T Beric, S Stankovic, B Todorovic, I Potocnik. 2018. Antagonistic potential of Bacillus spp. Isolates againts bacterial pathogens of tomato and fungal pathogen of pepper. Pestic. Phytomed. 33(1): 9-18.

Nurcahyanti SD, T Ariwiyanto, D Indradewa, J Widada. 2013. Isolasi dan seleksi pseudomonad flourescens pada risosfer penyambungan tomat. Berkala Ilmiah Pertanian. 1(1): 15-18.

Nurfitriani R, NPRA Krishanti, A Akghdiya, AT Wahyudi. 2016. Penapisan bakteri filosfer penghasil senyawa bioaktif anti Xanthomonas oryzae pv. oryzae penyebab penyakit hawar daun bakteri pada padi. Sumberdaya Hayati 2(1): 19-25.

Prathuangwong S, K Amnuaykit. 1987. Studies on tolerance and rate-reducing bacterial pustule of soybean cultivars lines. Kasetsart Journal Natural Science 21(4): 408-426.

Pratita MYE, SR Putra. 2012. isolasi dan identifikasi bakteri termofilik dari sumber mata air panas di songgoriti setelah dua hari inkubasi. Teknik Pomits 1(1): $1-5$.

Prayogo DP, HT Sebayang, A Nugroho. 2017. Pengaruh pengendalian gulma pada pertumbuhan dan hasil tanaman kedelai (Glycine max (L.) Merril) pada berbagai sistem olah tanah. Produksi Tanaman 5(1): 24-32.

Rudini B, F Ayustaningwarno. 2013. Kadar protein, serat, triptofan, dan mutu organoleptik kudapan ekstrusi jagung dengan substitusi kedelai. Nutrition Collage 2(3): $373-381$.

Sartoni M, A Nesci, A Formento, M Etcheverry. 2015. Selection of potential biological control of Exserohilum turcium with epiphytic microorganism from maize. Revista Argentina de Microbiología 47 (1): 62-71.
Sain SK, HN Gour. 2013. Pathological and physiobiochemical characterization of Xanthomonas axonopodis pv. glycines, incitent of Glycine max leaf pustules. Indian Phytopathology 66(1): 20-27

Schaad NW, JB Jones, W Chun. 2001. Laboratory Guide for Identification of Plant Pathogenic Bacteria. USA: Onacid.

Soesanto L. 2013. Pengantar Pengendalian Hayati Penyakit Tanaman. Depok: PT RajagrafindoPersada.

Stein T. 2005. Bacillus subtilis antibiotics: structures, syntheses and specific function. Mol. Microbiol. 56(4): 845-857.

Suhartanti M, PR Sarjono, ALN Aminin. 2010. Studi filogeni dan uji potensi enzim ekstraseluler (amilase, B-galaktosidase, protease, katalase) Isolat Alicyclobacillus sp. Gedong Songo. Kimia Sains dan Aplikasi 13(3): 13-3.

Sumartini, M Rahayu. 2017. Penyakit embun tepung dan cara pengendaliannya pada tanaman kedelai dan kacang hijau. Jurnal Penelitian dan Pengembangan Pertanian 36(2): 59-66.

Thomson JP, MJ Bailey, JS Fenlon, TR Fermor, AK Lilley, JM Lynch, PJ McCormack, MP McQuilken, KJ Purdy, PB Rainey, JM Whipps. 1993. Quantitative and qualitative seasonal changes in the microbial community from the phyllosphere of sugar beet (Beta vulgaris). Plant and Soil 150(2): 177-191.

Wartono, Giyanto, KH Mutaqin. 2015. Efektivitas formulasi spora Bacillus subtilis B12 sebagai agen pengendali hayati penyakit hawar daun bakteri pada tanaman padi. Jurnal Penelitian Pertanian Tanaman Pangan 34(1): 21-28.

Yanti Y, T Habazar, Z Resti. 2017. Formulasi padat rhizobakteria indigenus Bacillus thuringiensis TS dan waktu penyimpanan untuk mengendalikan penyakit pustul bakteri Xanthomonas axonopodis pv. glycines. Jurnal Hama dan Penyakit Tumbuhan Tropika 17(1): 9-18. 